\title{
India launches new plan for unconventional energy sources
}

\section{New Delhi}

AN ambitious plan to produce by the end of the century $15,000 \mathrm{MW}$ of electricity in India from sunlight, biomass, wind and microhydroelectric plants has been drawn up by the Department of Nonconventional Energy Sources (DNES). The target is half as much again as that set for nuclear electricity, but the plan has yet to win government approval.

One feature of the new plan is that decentralized energy systems would be established throughout India to meet local demands for fuelwood, cooking gas and irrigation power. According to DNES secretary Maheshwar Dayal, total energy generation from non-conventional sources by the year 2001 would be equivalent to 250 million tonnes of coal, or one-fifth of the total energy needs of India. Dayal says that the scheme "is well within the realm of practical possibility". The cost of the scheme is estimated at $\$ 40,000$ million, of which the government would put up 24 per cent and the rest would be palmed off on industry and energy cooperatives.

Under the DNES plan, about 2.5 million hectares of land will be brought under energy plantations coupled with power-generating units based on gasifiers and sterling engines. Energy crops on 1,000 hectares can generate $3 \mathrm{MW}$ of power, and a total of $6,000 \mathrm{MW}$ would be produced by the biomass project. Part of

\section{Nuclear plants spark protest}

\section{Bangalore}

ENVIRONMENTALISTS in the southern Indian state of Karnataka are up in arms at the central government's plans to build four nuclear power reactors at the coastal site of Kaiga. The intention is that two plants of 235-MW capacity should soon be built there, to be followed by two 500-MW plants at a later stage. The reactors will be based on the Canadian CANDU design, with natural uranium fuel and heavy water as a coolant.

One complaint is that the dense tropical forests surrounding Kaiga are an important natural resource, but the region is also seismically active. Other objectors point out that the proposed nuclear site is only $30 \mathrm{~km}$ away from India's largest naval base at Karwar, which could make it vulnerable to enemy attacks. Although the people of the region are mostly illiterate, environmental groups have made sure that they now understand the potential dangers of nuclear plants.

Radakrishna Rao the harvest would be for fuelwood.

DNES has estimated that more than $20,000 \mathrm{MW}$ of potential windpower exists in the coastal areas. It is proposed to generate $5,000 \mathrm{MW}$ of power from largescale wind farms and another 2,000 MW from solar thermal power stations. Some 1,000 micro-hydel stations will provide an additional 2,000 MW.

The plan also provides for 12 million big biogas plants to provide cooking gas, 50,000 solar photovoltaic and 50,000 wind pumps for lift irrigation and drinking water supply. Sewage from all major cities and towns will be treated and 50 MW of power produced from the sludge. Energy will be recovered from the effluent of all the 140 distilleries in the country and 40 projects are to be set up for recovering $160 \mathrm{MW}$ of power from solid municipal wastes. To save fuelwood, 100 million improved wood-burning stoves would be installed in rural homes to replace the inefficient 'chulahs' now in use.

Within the next three years, 5,000 villages are to be made self-sufficient in energy, using a combination of energy systems and devices. A Renewable Energy Development Agency has already been set up to finance, through soft loans, a large number of the non-conventional energy projects.

Photovoltaic modules are now manufactured in India and the raw material, pure silicon, is also produced indigenously on a commercial scale. But a good number of the projects under the DNES plan are likely to open a vast market for vendors from abroad. Present Indian projects for a solar thermal power station are based on US and West German technology. The five wind farms in operation use models developed by Denmark and the Netherlands. The small turbines needed for micro-hydel stations are not made in the country and India's first refuse incineration plant in New Delhi, which will generate $3.75 \mathrm{MW}$ of power from solid waste, is being set up by Denmark.
K.S. Jayaraman

\section{Chinese intellectuals need not fear fall from Party favour}

\section{London}

FEARS that the 'reorganization' of the Chinese University of Science and Technology last January (see Nature 325, $290 ; 1987)$ signalled the return of hard times for China's intellectuals seem to have been unfounded. The removal of university president Guan Weiyan, and vice-president Fang Lizhi, and the expulsion of the latter from the party, has not meant the termination of their scientific creers. Fang's "offence" was a serious one; he had allegedly advocated "bourgeous liberalism" and "total Westernization". A few days after his dismissal, the party general secretary, $\mathrm{Hu}$ Yaobang, who admitted favouring Fang's views in a self-criticism, had to resign.

Fang and Guan were immediately found posts by the Chinese Academy of Sciences, Guan in its Institute of Physics and Fang at the Beijing Observatory. Soon after, when the president of the Chinese Academy of Sciences, Lu Jiaxi, retired, the new president, Zhou Guangzhao, made it clear that the current drive against "bourgeous liberalization" did not mean absolute rigidity of outlook among academy personnel. "The academy will . . . allow different views. Debates can lead to truth", he said. And, he added "we still allow scientists like Fang Lizhi to work in the academy and present academic reports. The academy has not limited Fang's per- sonal or scientific activities."

One exponent of a more relaxed attitude to diversity of views among academics seems to be the prime minister, Zhao Ziyang, who since the resignation of $\mathrm{Hu}$ Yaobang has also been acting general secretary of the party. Addressing a group of delegates from the academy recently, he said that opposition to "bourgeous liberalization" should not develop at the expense of democratization, and that research institutes, in particular, should be one step ahead in democratization. Channels for discussion and dialogue between leading cadres and intellectuals must be opened up, he said, so that the intellectuals can have outlets for their views.

So long as Fang and Guan stick to research, it seems, the leadership is prepared to overlook recent political errors. But at the time of his dismissal, Fang was scheduled to visit Britain, to attend the Newton Conference in Cambridge in July. The conference organizers have had no communication from him since his acceptance of their invitation, which was dated in late December, before his dismissal. Recently, however, the Hong Kong journal Pai Hsing reported that Fang's trip to Britain will take place as scheduled, and that this is the personal decision of Zhao Ziyang. If Fang does indeed arrive in Cambridge, it will confirm Zhao Ziyang's assurances.

Vera Rich 